\title{
Crime Prevention through Interior Design for Museum in Surabaya
}

\author{
$1^{\text {st }}$ Sherly de Yong \\ Interior Design Department \\ Petra Christian University \\ Surabaya, Indonesia \\ sherly_de_yong@petra.ac.id
}

\author{
$2^{\text {nd }}$ Purnama Esa Dora Tedjokoesoemo \\ Interior Design Department \\ Petra Christian University \\ Surabaya, Indonesia \\ esa@petra.ac.id
}

\begin{abstract}
One of the fundamental aspects of humankind is security. Museums and galleries in Surabaya is viewed as less secure, as prove by the uncontrolled misuses that occurred such as vandalism to the burglary of exhibition hall objects. The museums ought to be a place that can show us about the past and can inspire us. On the other one hand, the museum ought to be genuinely available and open, then again it ought to likewise consider its security issues. Hence, the inside state of an exhibition hall needs consideration. The Crime Prevention through Environmental Design has been proven as an approach that has highly affected decreasing wrongdoing rates and giving a suspicion that all is well and good for groups in nations. In any case, unique physical situations, distinctive improvement tenets and norms, socio-political measurements and socio-social states of various groups take into consideration contrasts in the utilization of the idea to exhibition halls in Surabaya. In Surabaya, this counteractive action for crime prevention in a museum has not gotten adequate consideration. This was demonstrated by the nonattendance of directions or advancement approaches from the government for dodging the event of wrongdoing in the exhibition hall. In view of the truth and foundation of the above issues, the reason for this exploration is to think about the idea of CPTED at the museums in Surabaya. The technique utilized is the strategy of the design thinking approach. The phases of this design thinking method are: investigation (understanding the hypothesis and question of research), distinguishing proof (definition, determination, and issue amalgamation with standardizing study examination approach) brainstorming, and visualization (using 3D model and set of drawings). This research is required to enhance the ability and capability of specialists in understanding the hypothesis of space identified with the idea of wrongdoing avoidance inside the museum. The results of this study will be used to update information on crime prevention, educate the public and designers, set of proposed design for crime prevention in and prevent criminal acts so that expected in the long term can contribute in the prosperity process of the people of Indonesia
\end{abstract}

Keywords-component, formatting, style, styling, insert

\section{INTRODUCTION}

A museum should be preserved as they are useful in inspiring and educating the public. Historic buildings teach us about the past, the source of the present and the future. Challenges and security dilemmas in historic buildings one of them is balancing public security with the protection of historical buildings, historic objects, historical art objects, historic sculptures and historical recordings. One way to improve public security and protection of historical buildings and objects is by using Crime Prevention Through Environmental Design (CPTED). The physical environment of buildings and spaces can serve as a medium for crime prevention

In crime prevention theory, Katyal in Architecture Control [1], developed a strategy to condition the environment as crime prevention. There are three components actively involved in the conditioning of crime prevention, which is mechanical, organizational and natural components. Mechanical components are components related to crime prevention through mechanical equipment such as CCTV, alarm, and others. The organizational component is related to its active human involvement, such as adding a security guard or other security personnel. While the natural component is a component associated with the prevention of crime through the setting of space, such as the arrangement of patterns of space and furniture and circulation in such a way by the interior designer so that space naturally able to help prevention of crime. In each component, there are four parts that can be analyzed (natural surveillance, territoriality, community building and protecting target hardening). [2].

Security conditions in historical buildings, especially the museum are still very vulnerable, as evidenced by the theft of historical objects, vandalism of buildings-interior-historical objects that occurred in historic buildings such as museums. Therefore, this study will examine the concept of CPTED and proposed design solutions for interior museums in Surabaya.

\section{CONCEPT OF CRIME PREVENTION THROUGH ENVIRONMENTAL DESIGN}

Since the proposed of Crime Prevention through Environmental Design (CPTED)'s approach by Jeffrey, this theory of CPTED has been evolved. The basis of the theory in the first generation is the study of space and space relating to environmental recognition, security and an environmental defense that focuses on design solutions in reducing or preventing property crime [3] [4] [5] [6] [2]. Then in its development towards the second generation of CPTED, the aspect that gets the main concern is that this concept not only emphasizes aspects that are the only physical environment but involves social factors. This second generation uses risk assessment, socio-demographic profile, community participation [7]

Initially, strategies in the CPTED approach include: 1) Natural supervision, to maximize oversight opportunities, 2) 
Control access naturally, through designs that can control entry and exit to and from a specific space, 3) Strengthening and maintaining territory/territory by forming identified communities and zones within the community. But in the development of crime prevention theory, Katyal in Architecture Control developed a mechanism strategy to condition the environment as crime prevention, into 4 parts: natural supervision, territoriality, community building and protecting crime targets. This is an important point in the crime prevention mechanism [1] [2].

The first strategy within the supervisory concept within CPTED limits the crime by increasing the perception of the perpetrator about the possibility of being watched and seen by the person either naturally or mechanically [1]. The application of the concept of natural oversight is capable of influencing the decision of the offender. Research in criminal behavior shows that the decision of the perpetrator to commit a crime is strongly influenced by the signals of perceived risks by the offender. In addition, the concept of natural supervision will reduce feelings of fear from the community. In order for this concept to work properly, it is necessary to maximize the visibility of people, the existence of free design (eg made of glass walls and low wooden fences) for parking areas and building entrances including doors and windows that lead out onto the street, sidewalks and front porches. Good lighting is also one of the design concepts of natural supervision in the environment. In addition, the variation of activity from users around the environment can help in the creation of natural surveillance concepts.

So in general, the concept of natural surveillance is closely related to the conditioning of the surrounding environment so as to enable the formation of natural oversight. The results of research on the prevention of crime through the environment mentioned that the perception of the concept of natural supervision with the highest security of a public space is supported by the presence of good lighting arrangement, an openness of a public space, and variation of activity from users around the public space.[1]

The next strategy: natural control and natural access control, are primarily directed at creating a perceived offender by keeping users, monitoring and denying access.

\section{RESEARCH METHODOLOGY}

The applied research method used is the design thinking method combine with crime risk evaluation. The crime risk evaluation is used to understand more about the issue in the Museum Kota Surabaya. The design thinking method is used at the ideation stage. The methods used at each phase are described in the following research stages:

1. Investigation (understanding the hypothesis, question of research and site opportunity). In this stage, we were doing literature study on the concept of crime prevention through interior space design; field study using observation method, risk assessment, and digital documentation questionnaire to document the existing condition in the field. Sources of data were obtained through literature studies and field exploration of Museum Kota Surabaya. The results at this stage are data on conditions in the field and the literature on the concept of crime prevention in the interior. The investigation is carried out from the literature to gain an understanding of the concept of crime prevention, and from the field to obtain issues related to crime prevention in museums.

2. Evaluation (using the Environmental Visual Assessment (EVA) and Security Audit to understand the risk rating and produce CPTED treatments for the museum). In this stage, we were doing reviewing, selecting, classifying and drawing conclusions after comparing theories and field objects with comparative analysis methods and normative critiques. Data sources at this stage are literature data and research objects. This stage is done by analyzing the theory of crime prevention concept and building standard of public space to get parameters that can be used to see the symptoms of problems in the object of research. The results of this stage are the parameters of the literature analysis and the identification of the problems. Environmental Visual Assessment (EVA) and Security Audit are two methods that will be used in this stage. Environmental Visual Assessment (EVA) is a method to identify issues related to flooding, fires and possible theft. EVA is done by observing by walking around inside and outside the museum to identify areas that allow the occurrence of the threat of theft, fire, and flood.

3. Ideation (create alternative ideas from the problems). In this stage, we were using the brainstorming method: related context to create alternative ideas as a solution from the problems and sketches of proposed solutions in museum interiors as the result of this stage.

\section{RESEARCH RESULTS}

The analysis begins with the analysis of CPTED concept theory which will be used as the foundation of CPTED concept benchmark analysis on the museums that have been surveyed. Following the benchmark analysis, the next step is to conduct an analysis of the applicability of the CPTED concept to the spaces in the related Museum Kota Surabaya and risk assessment analysis to get the problem mapping in the museum. The results of this study consist of three results. One is the results from theory CPTED in the museum, the Environmental Visual Assessment (EVA) and security audit for Museum Kota Surabaya. The last one is the proposed design as the solution for Museum Kota Surabaya.

\section{A. Result from Theory Crime Prevention through Environmental Design in the museum}

In crime prevention theory, Katyal in Architecture Control developed a strategy to condition the environment as crime prevention. There are three components actively involved in conditioning crime prevention, which are mechanical, organizational and natural components. Mechanical components are components related to crime prevention through mechanical equipment such as CCTV, alarm, and others. The organizational component is associated with active human involvement, such as adding security guards or other security personnel. While the natural component is a component associated with the prevention of crime through the setting of space, such as the arrangement of patterns of space and furniture and circulation in such a way by the 
interior designer so that space naturally able to help prevention of crime. [1]. In each component, there are four (4) parts that can be analyzed, namely: natural surveillance, territoriality, building community and protecting the target from crime [2].

These four components can be discussed from a mechanical, organizational and natural point of view. In this research will be seen which components appear from each case study, then design solution. Natural components, associated with the natural spatial aspects that can help prevent crime. As for mechanical components, only tools will be displayed that can help crime prevention. For an organizational component is a component involving human organization such as a security team or organizational structure of the museum. The following will explain the CPTED theory used and the discussion of each part of the concept of surveillance. (see fig 1)

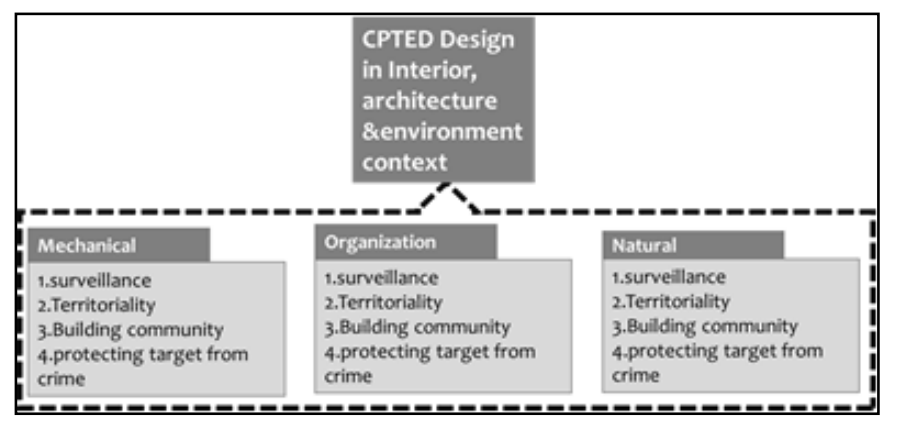

Fig. 1. The theory of Crime Prevention Through Environment Design

The concept of natural surveillance is required in crime prevention through design. Some of the things that are needed in this natural surveillance concept include: maximizing people's visibility (made of glass walls and low wooden fences) for parking areas and building entrances including doors and windows leading out onto the street, sidewalks and front porches. Good lighting is also one of the design concepts of natural surveillance. In addition, the variation of activity from users around the environment can help in the creation of natural surveillance concepts. So in general, the concept of natural surveillance is closely related to the conditioning of the surrounding environment so as to enable the formation of natural oversight.

As Flusty discloses in Lockton [8], space can be classified and designed to block or filter users. There are 5 types of classification of space (1) stealthy space (2) slippery space (space visible but not approachable) (3) crusty space (space that cannot be accessed due to obstacles) (4) prickly space (space that cannot be occupied comfortably due to walking, sitting and standing activities) and (5) jittery space (continuous space under supervision). The existence of layout design based on this type of space will facilitate the surveillance pattern. So it can be concluded that the mechanism for this concept is most influential is (1) the pattern of classification and arrangement of space and furniture (space is divided into 5 types: stealthy, slippery, crusty, prickly and jittery space); and (2) the height limit of the space / furniture that will facilitate monitoring where the space limit/furniture with a height of $150 \mathrm{~cm}$ provides visual and privacy limits compared to the height of 85 cm; (3) mechanism for mechanics, can use mechanical tools such as CCTV.
Strengthening of the territory is used to increase one's understanding of the importance of space. The environment with this territorial concept illustrates two mechanisms of territorial concepts. [9] First: space with a territorial concept that can create a sense of ownership (personalization space) or the mechanism of personal control territory. The control mechanism of the personalization of a space is always related to the identity of the self and the marking of the place. Second: space with a territorial concept that can create a sense of security (defensible space) or Mechanism of defense control. The hierarchy and type of territory are necessary to create good feelings and help maintain a person's sense of security (hierarchy of territory is a clear marker between private, semiprivate and public spaces). This hierarchy of territory is important in societies that need security. Strengthening of the territory is strengthened by using buildings, fences, sidewalks, signs, lighting, and landscaping to express the property (personalization) and define public spaces, semi-public and private (defensible). There are three things that must be considered so that the mechanism of this territory can be applied optimally, namely: (1) boundaries between areas; (2) symbolic boundary; (3) supervision and control of space. These three things are applied directly to the category of natural territory. While the mechanical territory can be optimized by adding a mechanical system wayfinding/signage system that allows users to know the territorial limits of a region.

In the concept of community building, it can be done through the socialization and training of the individuals involved in the space, such as an organizational structure for people who work in the building or organizational structure for security persona. Things that must be considered for the mechanism to build a community naturally is the use of other communities around the area for example by putting a taxi community around the building. Whereas the mechanism of building an organizational community is more involving the organizational structure for people who work in the building and personal security.

Target strengthening is used to protect protected objects. Strengthening targets is based on the assumption that designs can help users or objects to be protected. There are two things that must be considered for the mechanism of this natural target strengthening can be applied optimally, namely: (1) the design of the object; (2) design to protect the user. As for the mechanism of strengthening the mechanical target is to strengthen.

\section{B. The result from the Environmental Visual Assessment (EVA) and Security Audit}

To carry out the prevention analysis of crime through design, there are 2 stages. The first is by conducting Environmental Visual Assessment (EVA) and Security Audit. Both ways will be used to understand the security situation of the relevant museums so that later it can be used to build an analytical framework to review case studies. The second stage is to conduct an applied analysis of CPTED theory on rooms within the museum. The analysis is done on the security system (both passive and active) and the Museum Kota Surabaya's fire system in the perimeter area outside the museum, main entrance and surroundings, display area, receptionist, and 
security area. Here are the more detailed pictures showing the security system and EVA-Security Audit-related fire system at this museum (see fig 2).

\section{Outside perimeter}
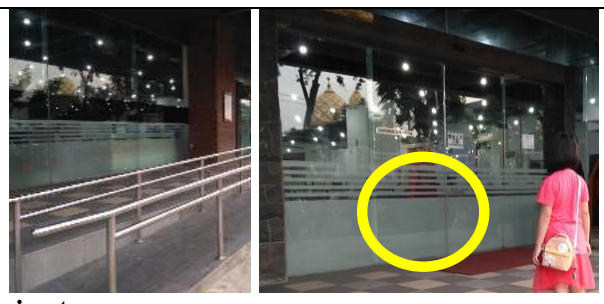

The outer barrier of the building made of glass walls is still functioning well and has no damage. The entrance of the building is made of automatic sliding doors using motion sensors. As for the active security system using an electronic lock on the hinge. In addition to automatic doors, outside the building there is also a CCTV camera as an active security system.

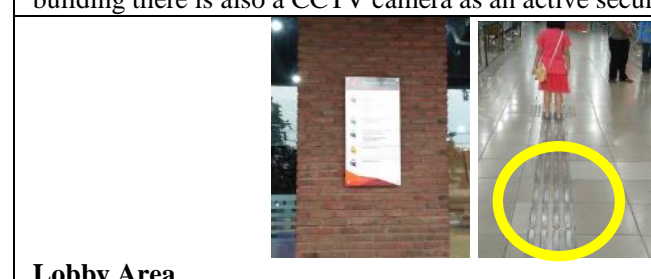

Lobby Area

There are directions and tactile paving that can help direct visitors. Directions and tactile paving this can indeed help direct visitors, but it would be better if supported by security officers for better security system.

\section{Entrance area}

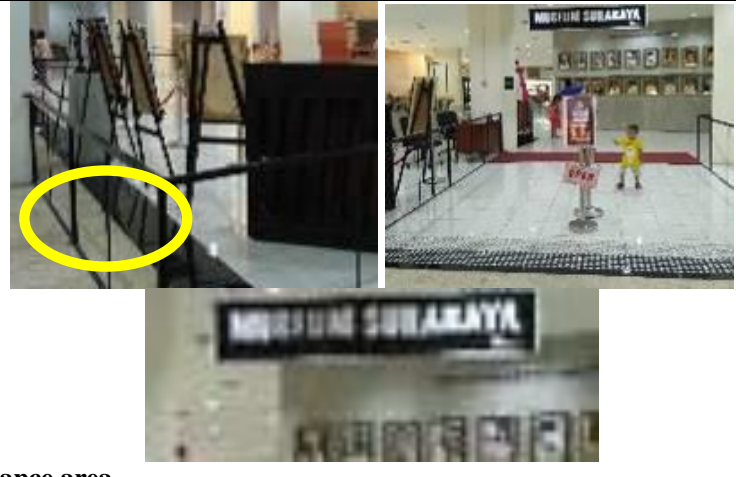

The barrier outside is made of guardrail. It is still functioning well and has no damage. But this guardrail is not recommended as a barrier of museum space. We recommend that the limits of the museum space using a ceiling high-wall to improve security. Preferably in this area other than the active security system CCTV camera, also added officers (both security officers and receptionists) in addition to the passive security system (since there is no receptionist at the entrance area to help guide visitors). There is already a signage "Museum Surabaya", but this museum needs to be equipped again with directions to make it easier to direct and manage visitors

\section{Security area}

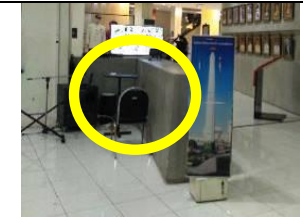

In this area there is a computer to control the CCTV camera in the museum. This area is not isolated, so visitors can freely access this area. This area should be more closed and the guard should not leave this area.

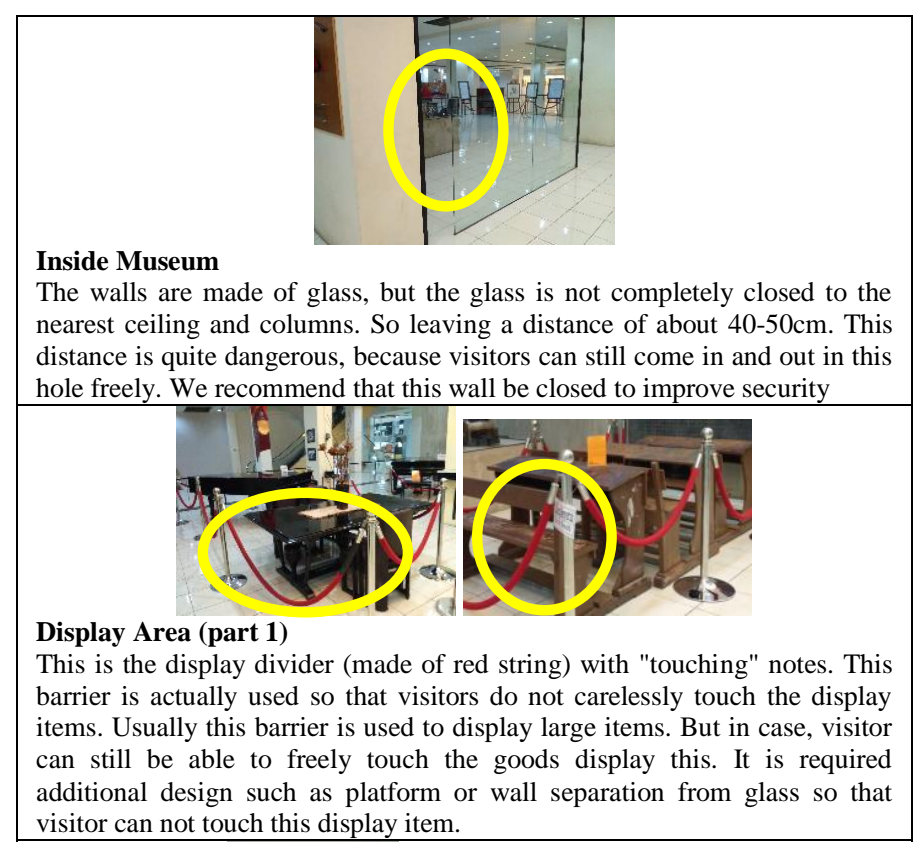
visitor can not touch this display item.
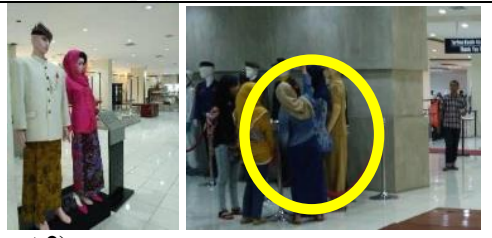

Display Area (part 2)

The picture on the side shows the visitor can still freely touch this display item even though there is already a red rope barrier. There should be design changes such as adding a platform or wall separation from the glass so that visitors can not touch this display item.

Display Area (part 3)

This is the display for historic and valuable items. This type of barrier is actually used so that visitors do not touch the display items. Because this display is closed, there is no need to add note "forbidden to touch".

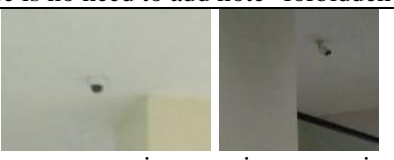

There is a CCTV camera as an active security system in this museum. As for the fire system, using APAR or hydrant located outside the museum area. The museum should also be added to APAR to help improve the security of the fire system.

Fig. 2. Result of Environmental Visual Assessment and Security Audit in Museum Kota Surabaya

Based on the above description of EVA-Security Audit then things that can be added to improve the prevention of crime in the museum is to improve the design for:

1. Concept of surveillance required the improvement of natural surveillance through the processing of spatial patterns, circulation and furniture and mechanical supervision through the increase of CCTV location

2. Concept of territory it is necessary to increase the physical boundaries of clear natural territory through the private-semi private-public zone processing and the 
limitation of the mechanical territory through the use of clear symbolic boundaries such as space markers, wayfinding maps etc.

3 Concept of building community is necessary to increase in natural terms by utilizing the existence of other communities around the museum. As for the organization community needs to be built and held by the museum.

4. Concept of target hardening, it is necessary to increase in natural terms such as furniture designs that can protect the target and in mechanical terms such as mechanical key enhancements or other mechanical devices.

These concepts are mainly applied to public areas such as main entrance areas, receptionists, display areas and semipublic areas such as storage and security rooms. Below is the table conclusion of analysis CPTED Concept applied at Museum.

TABLE I. TABLE OF CONCLUSION ANALYSIS CPTED CONCEPT

\begin{tabular}{|c|c|c|c|c|}
\hline \multirow[b]{2}{*}{ Area } & \multicolumn{4}{|c|}{ Concept } \\
\hline & Surveillance & Territory & $\begin{array}{l}\text { Building } \\
\text { Community }\end{array}$ & $\begin{array}{l}\text { Target } \\
\text { Hardening }\end{array}$ \\
\hline $\begin{array}{l}\text { Main } \\
\text { Entrance }\end{array}$ & $\begin{array}{l}\text { Natural; } \\
\text { Mechanical }\end{array}$ & $\begin{array}{l}\text { Natural; } \\
\text { Mechanical }\end{array}$ & $\begin{array}{l}\text { Natural; } \\
\text { Organization }\end{array}$ & $\begin{array}{l}\text { Natural; } \\
\text { Mechanical }\end{array}$ \\
\hline $\begin{array}{l}\text { Receptionist } \\
\text { Area }\end{array}$ & $\begin{array}{l}\text { Natural; } \\
\text { Mechanical }\end{array}$ & $\begin{array}{l}\text { Natural; } \\
\text { Mechanical }\end{array}$ & Organization & Mechanical \\
\hline $\begin{array}{l}\text { Display } \\
\text { Area }\end{array}$ & $\begin{array}{l}\text { Natural; } \\
\text { Mechanical }\end{array}$ & $\begin{array}{l}\text { Natural; } \\
\text { Mechanical }\end{array}$ & Organization & $\begin{array}{l}\text { Natural; } \\
\text { Mechanical }\end{array}$ \\
\hline $\begin{array}{l}\text { Storage } \\
\text { Area }\end{array}$ & Mechanical & Mechanical & Organization & Mechanical \\
\hline $\begin{array}{l}\text { Security } \\
\text { Area }\end{array}$ & $\begin{array}{l}\text { Natural; } \\
\text { Mechanical }\end{array}$ & $\begin{array}{l}\text { Natural; } \\
\text { Mechanical }\end{array}$ & Organization & Mechanical \\
\hline
\end{tabular}

Proposed Design as Solution for Museum Kota Surabaya

From above description of EVA-Security Audit then these are the proposed design as solution for Museum Kota Surabaya: (1) The pattern of classification and spatial arrangement and clear furniture (Area Main entrance including prickly space; Reception Area is slippery space; Security Area is crusty space; Area of Circulation Display includes prickly space; Display Area includes jittery space; Storage Area is stealthy space) and groupings for spaces that need to be adjacent. The security area should be closed and linked to the receptionist area to help improve natural surveillance for entrance/exit area, important display, outside/window display and important area such as storage area. (See Fig 3)
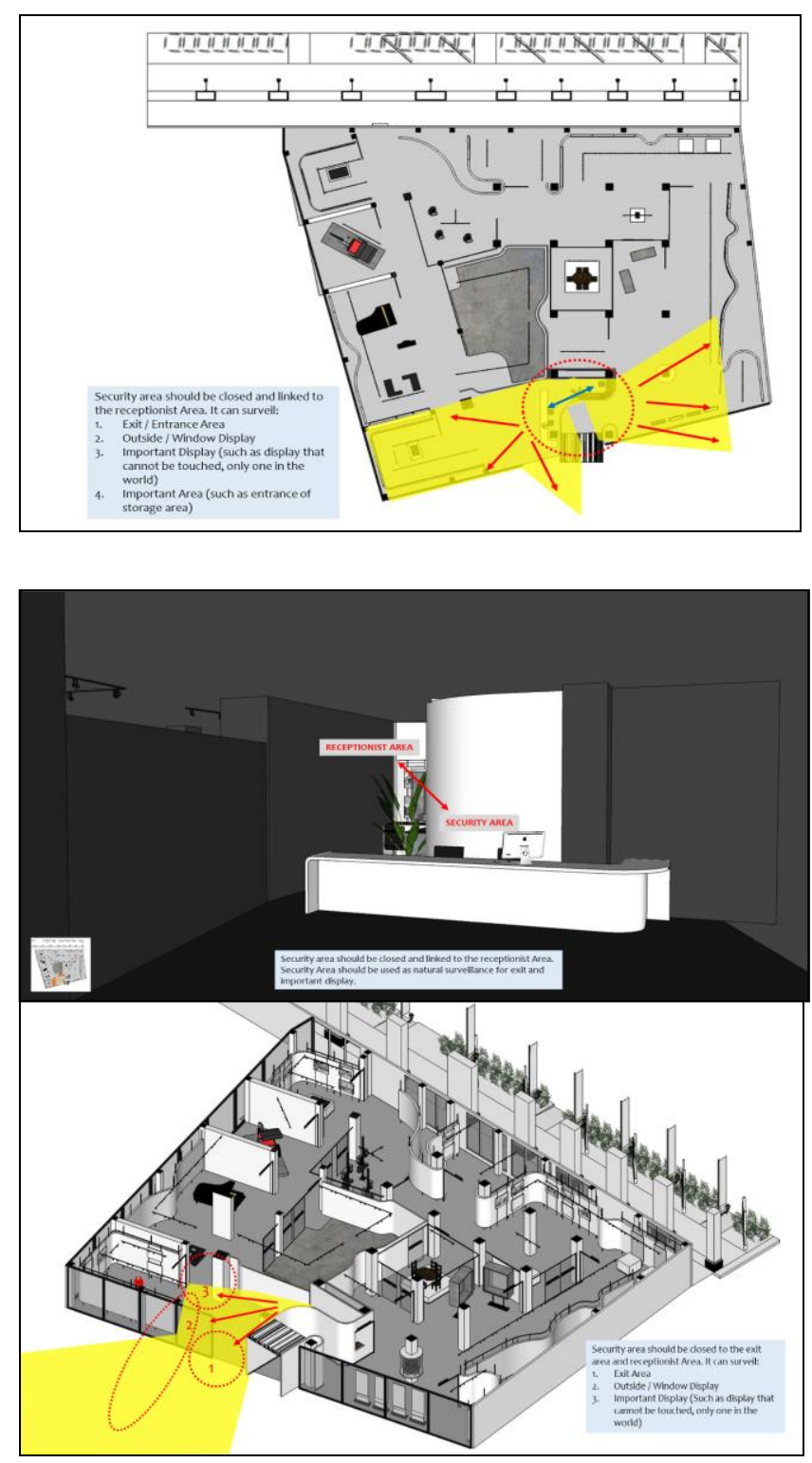

Fig. 3. Security Area and Reception Area should be close and designated for Natural Surveillance

(2) Utilization of tempered glass for displays and for outdoor barriers. Window displays as outdoor barriers, can be used as the natural surveillance. The window display should also be equipped with mechanical and electrical target hardening such as CCTV, window alarms, and window grill to prevent thievery. (See Fig. 4). 


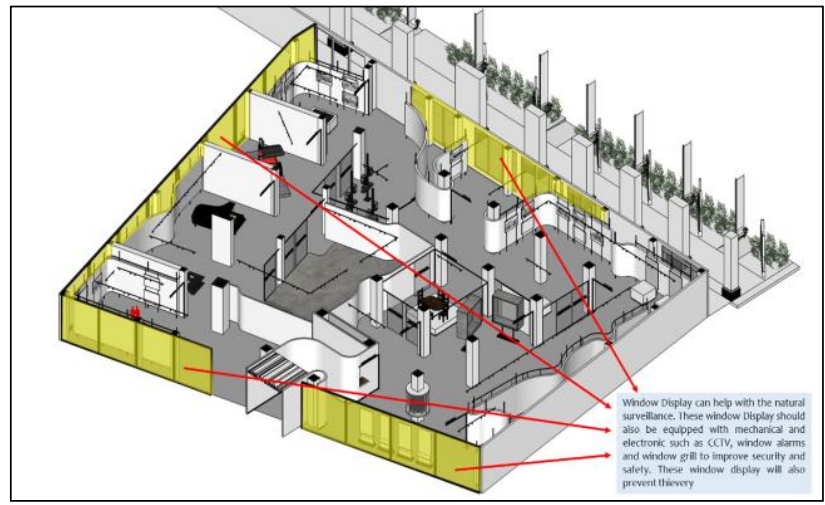

Fig. 4. Window Display as Barrier and Natural Surveillance

(3) Circulation direction and order and a certain distance. The Circulation in the museum should be linier circulation to help control visitors. The Entrance and Exit Area should be located close to each other to control visitors. (See Fig. 5).

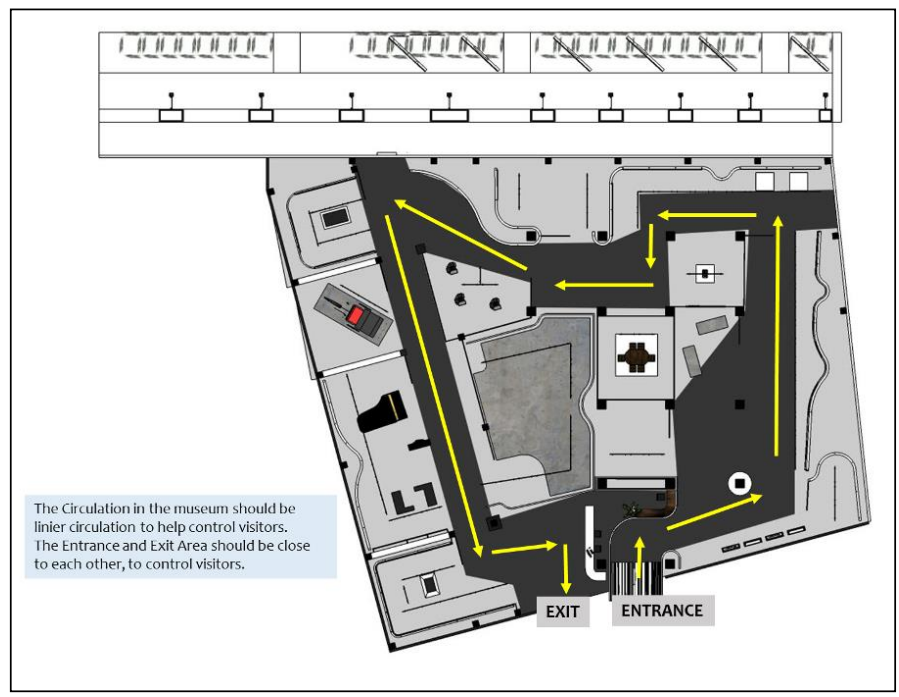

Fig. 5. Linier Circulation for Museum

(4) Height limits for areas that need surveillance between $85-130 \mathrm{~cm}$. This height limits will help the security officer, receptionist or other users to surveil surrounding area. (See Fig. $6)$.

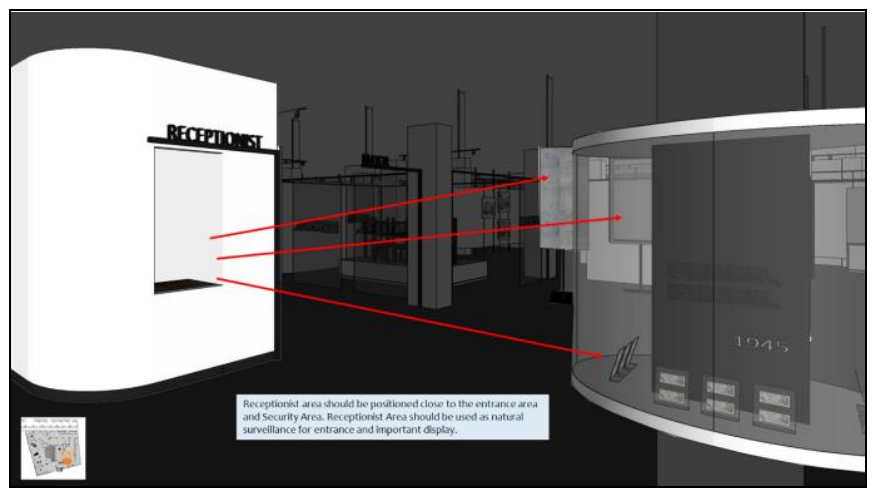

Fig. 6. Height Limits for Display Area

(5) Furniture design for display to strengthen the target and protect the display object. This mechanism is used to optimize the applied concept of CPTED in the museum. For example, the important display (display for object that cannot be touched because of it rareness) should be display in a close-tight, humid free, fire and flood proof, and bullet proof. These display usually for historic and important document, or expensive items such as diamond. A platform display can be used to display bigger 3D object such as furniture, car, music instrument, mannequin, etc. The platform design is made so people still can see the object closely and touch it but not using it. (See Fig. 7).

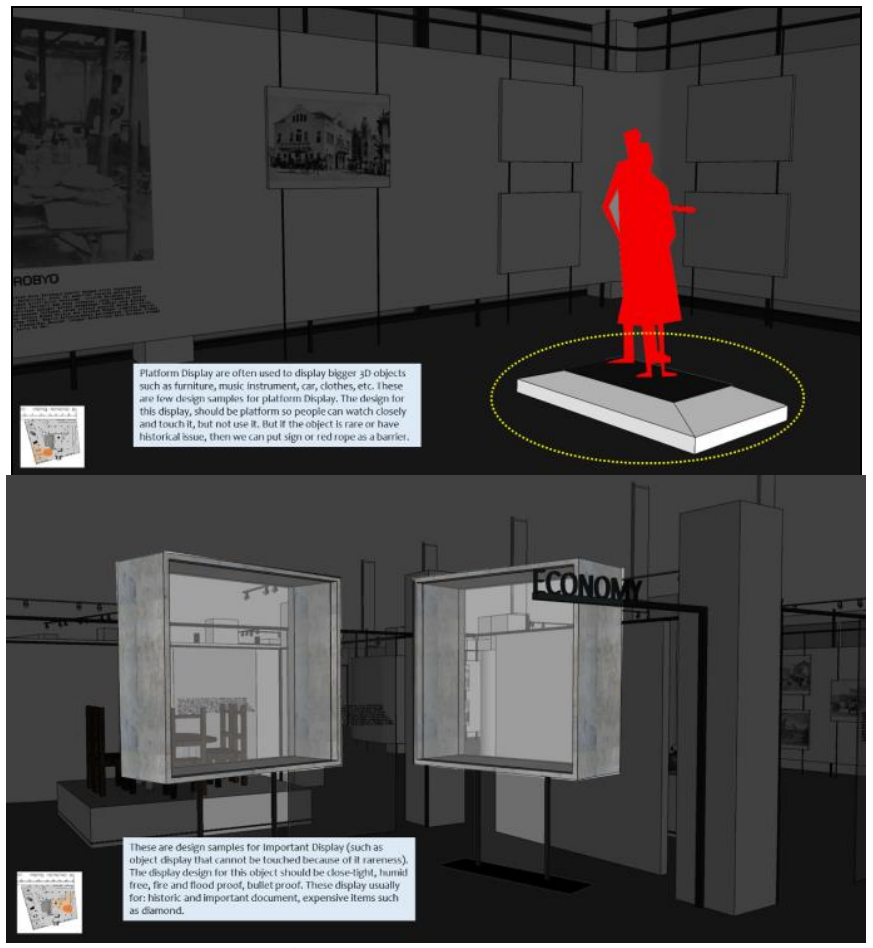

Fig. 7. Furniture Design for Display Area

(6) The use of mechanical tools such as CCTV, APAR, clear signage / wayfinding, alarm etc. (See Fig. 8)

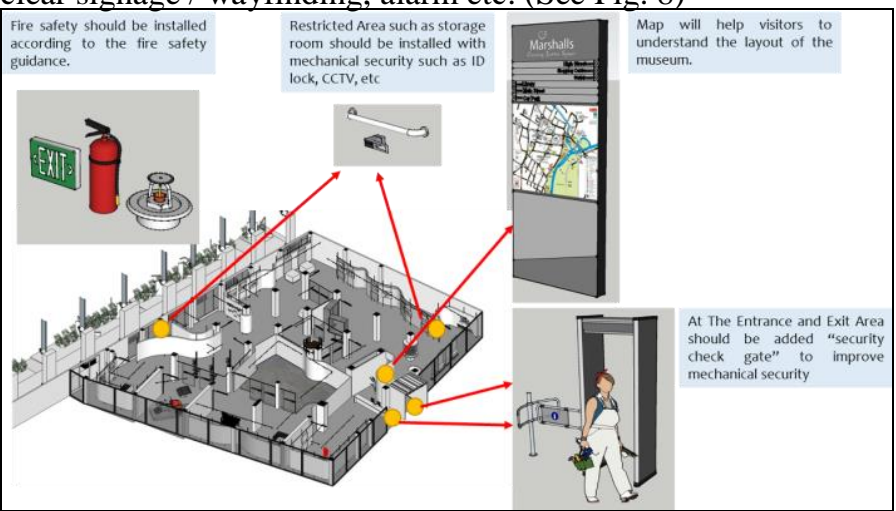

Fig. 8. Various Mechanical CPTED for Museum

(7) Building a community of nature and organization with more involving the management of the room. 


\section{ACKNOWLEDGMENT}

This study was supported by Interior Design Department, Petra Christian University Surabaya-Indonesia, ARA Studio and family. The authors are grateful to this support.

\section{REFERENCES}

[1] Katyal, N. K. "Architecture as Crime Control". Yale Law Journal Vol 111,2002

[2] Clancey, G., Murray, L., \& Fisher, D. "Crime Prevention Through Environmental design (CPTED and the New South Wales crime risk assessment guidelines: A critical review". Crime Prevention and Community Safety vol 14.1, 1-15, 2012

[3] Lynch, K.. "The Image of the City". Cambridge: MIT Press, 1960

[4] Jacobs, J. "The Death and Life of Great American Cities". New York: Vintage Books, 1961

[5] Newman, O. "Defensible Space People and Design in Violent City". London: Architectural Press., 1973

[6] Gardiner. "Design for Safe Neighbourhoods: The Environmental Security Planning and Design Process." Washington: US Department of Justice, 1978

[7] Saville, G. "2nd Generation CPTED: An Antidote to Social Y2K Virus of Urban Design,” 2nd Annual International CPTED Conference, 3-5 desember 1997. Orlando, 1997.

[8] Lockton, D. "Design with Intent". [Online]. Avalaible: http://architectures.danlockton.co.uk/architecture-of-control-in-the-builtenvironment/, 2011

[9] Agustin, S. "Place Advantage: Applied Psychology for Interior Architecture". New Jersey: John Wiley \& Sons Inc, 2009 